\title{
Conceptual Perspectives on State Fragility
}

\author{
D.P. Elagin ${ }^{1,2}$ \\ ${ }^{1}$ Moscow State Institute of International Relations (University) \\ 2 Peoples Friendship University of Russia
}

\begin{abstract}
The article explores scientific discourse on the phenomenon of state fragility and reviews contemporary research that aims to uncover what factors account for the emergence of states that are vulnerable to risks and crises and lack the capacity to deliver a response on their own. In order to achieve this goal, the author analyzes the evolution of the state fragility concept and reviews the literature on its causes. The article finds significant advancement in scientific thought about fragile states, acknowledging their continuous and multi-dimensional nature (the 'ALC' and 'OECD' approaches). However, these approaches tend to view fragile states as a deviation from the European nation-state model and focus more on the attributes of fragility (inability to perform core functions of the state or lacking the capacity to cope with risks and crises) while failing to produce a precise explanation for its causes. Hence, there is a need to analyze the process of fragile states formation and its consequences, i.e., to look at the macrohistorical dimension of state fragility. A better understanding of the historical context of state fragility and stricter identification criteria for the subgroup of severely and chronically fragile states allows identifying some structural explanatory factors such as rigidity of pre-independence colonial state borders, heterogeneity of population, and preferences that constraints collective action and small economic size. The literature review presented in the article finds that fragile states often have an insufficient tax base to guarantee the efficient provision of public goods. There are also agency factors that contribute to increased state fragility. This review also finds that imperfect political institutions may produce kleptocratic political regimes detached from the population's interests and irresponsive to them.

Consequently, they are likely to deny or limit access to public goods for some population groups. A combination of these factors is likely to create weak and fragile states, with the extent of fragility being context-specific. Recognizing the impact of the factors discussed in the article may help produce better policy responses to various development problems that plague fragile states.
\end{abstract}

Keywords: fragile states, state fragility, causes of state fragility, chronic fragility, the political economy of state fragility, failed states, state failure 
7 he issues of "stateness," i.e., the state's ability to perform its core functions, has long been a subject of scientific debate (Ilyin 2011; Jackson 1990; Jackson, Rosberg 1982; Migdal 1988; Nettl 1968; Political Atlas of the Modern World... 2010; Rotberg 2002). There have always been states that performed poorly regardless of the standards for their assessment. States continue to decline into failure or fragility due to the effect of some recent events and crises, for instance, the Arab Spring (Buterbaugh et al., 2017).

The attempts to categorize such states commenced in the 1970s when the UN introduced the least developed countries (LDC) group ${ }^{1}$. However, this categorization was based solely on socio-economic grounds and failed to capture a diversity of problems these mostly post-colonial and weak states faced. In the 1990s, they drew growing scientific attention and at first were referred to as "failed states" (Helman, Ratner 1993), amid recognition that such states can generate not only internal grievances and instability but also global security threats. Since then, several new concepts have emerged to comprehend better what drives them to become weak and how the global community can respond to their weakness. Currently, the most widely used concept is "state fragility", that has become more popular among scholars and policymakers since the mid-2000s ${ }^{2}$.

This concept turned out to be preferable as it is devoid of some of the shortcomings inherent in previous attempts to identify a group of countries facing severe development problems and lacking the capacity to solve them. Firstly, it was a departure from a categorical notion of state failure (which implies that a state can not change its fortunes) and acknowledged that fragility is a continuous phenomenon so that that different states may be fragile to a different extent. Secondly, state fragility soon incorporated a multi-dimensional approach to stateness, thus recognizing that state performance in one area may be independent of its performance in other areas.

State fragility has been a subject of extensive scientific research, which has covered the phenomenon itself and its definition (Baliamoune-Lutz, McGillivray 2011; Bartenev 2017; Bøås 2017; Grimm et al. 2014), attempts at the measurement of state fragility (Ferreira 2017; Mata, Ziaja 2009), its causes (Brinkerhoff 2011; Collier 2007, 2009; Lambach et al. 2015; Shevskiy 2017), costs and implications for development (Ault, Spicer 2019; Naudé et al. 2011), as well as the international response to fragile states' problems (Chauvet, Collier 2004; Di John 2010; Faust et al. 2015; Feeny, McGillivaray 2009; Gisselquist 2014, 2015).

At the same time, the concept itself has been subject to criticism from both scholars and political leaders of the states, which have been labeled "fragile." Some critics rendered the concept useless and harmful and called for its abandonment because it is too vague and obscures the diversity of problems these states face (Call 2011; Nay

\footnotetext{
1 United Nations. 1971. General Assembly, 26th session: 2027th plenary meeting, Monday, 20 December 1971, New York. URL: https://digitallibrary.un.org/record/736384 (accessed 10.08.2021).

2 However, other terms remain in use and are often applied in a more or less synonymous way.
} 
2014; Saeed 2020). The "State fragility" concept is also criticized as it has been used to justify international interventions based on the belief in the convergence of all nationstates (Hagman, Hoehne 2008). Meanwhile, political leaders of fragile states point at the danger of marginalization in the eyes of investors ${ }^{3}$ that may hamper their economic development.

Although the causes of fragility have received coverage in the literature, there is no definitive answer to why it happens. Given the multi-dimensional nature of the phenomenon, it is evident that different factors may cause a change of fortunes and a downslide "from agile to fragile." Hence, researchers analyzed the impact of conflict (Aliyev 2017; Taylor 2014), poverty (Collier 2009; Naudé et al. 2011), external shocks (economic, ecological, or foreign intervention (Burke et al. 2009; Ismail 2016; Miguel, Satyanath 2011)) and many other variables. However, the authors recognize a potential for reverse causality, with some of them being the consequences of fragility.

In this article, the author argues that there is a need for a more in-depth analysis of causes and the macrohistorical dimension of state fragility. The article reviews the evolution of the definitions of fragility and fragile states, the literature on the causes of state fragility, and the genesis of fragile states to identify better factors that might explain rigid and chronic state fragility, which may help provide a more solid basis for existing scientific assessments. Therefore, the article shifts focus to factors that make states likely to become severely or chronically fragile. This review finds that although the research on the causes of fragility notes potential multiple causality in explaining a downslide into the category of fragile states, there is still insufficient understanding of why states are likely to become fragile. The article highlights that fragile states' stateformation dynamics are different from those typical of resilient and stable ones, which is likely to produce structural and agency factors that increase their vulnerability and fragility. Understanding these historical differences can be crucial for the explanation of modern fragile states' shortcomings in achieving sustainable economic growth and social stability (Tilly 199explaininge targeted development policies in place for fragile states.

As the nature of the phenomenon is complex (Baliamoune-Lutz, McGillivray 2011; Lambach et al. 2015), it is increasingly difficult to formulate a comprehensive list of fragile states. Besides, as fragile states are a rather diverse group, there is a need to understand better whether the concept retains its practical and analytical value or this diversity produces conceptual stretching (Collier, Mahon 1993). Therefore, the article focuses on states rendered fragile by such international institutions as the World Bank ${ }^{4}$ and the $\mathrm{OECD}^{5}$. The reasoning for that is the following. First, this group is formalized

\footnotetext{
3 UN. 2009. Address by Pierre Nkurunziza, President of Burundi, to the United Nations General Assembly, 18 March 2009. URL: https://www.un.org/en/ga/president/63/pdf/calendar/20090318-education.pdf (accessed 10.08.2021).

4 The World Bank denotes situations in states as fragile and conflict-affected. World Bank. 2021. FY21 List of Fragile and Conflict-affected Situations. URL: http://pubdocs.worldbank.org/en/888211594267968803/FCSList-FY21.pdf (accessed 10.08.2021)

5 OECD. 2020. States of Fragility 2020. Paris: OECD Publishing. P. 24. DOI: 10.1787/ba7c22e7-en
} 
by international institutions, and they are prioritized as the recipients of official development assistance. Second, they share more characteristics that justify the application of the concept.

The interest in this subgroup of states (the most unstable and fragile, and even chronically fragile ${ }^{6}$ ) follows from the fact that they may pose a threat to global stability and security, possibly generating regional conflicts through spillover effects (Iqbal, Starr 2008). These states lack political stability, cannot control their borders, and perform other core state functions, whereas aid and development discourses are not relevant for them without political reform. Consequently, the question arises of how they should be organized. Lack of structures that can hold a state together can be traced to historical factors and needs a more profound analysis - regimes and orders change, though informal institutions persist and prevent "development." Hence, there is a need for more effective strategies of external assistance, which should be based on better evaluation of national contexts ${ }^{7}$. Although donors prioritize, it is often absent, and no other instruments can be applied to improve development outcomes for fragile states.

The review finds two main approaches to disaggregating state fragility. In the article, they are referred to as functionalist or "ALC" (which stands for authority, legitimacy, and capacity), and the Organization for Economic Cooperation and Development (OECD) approaches. ${ }^{8}$ (Carment et al. 2010, 2015). The former pays specific attention to a state's ability to perform its core functions, such as maintaining control over its territory and monopoly over the use of force and violence, as well as core public goods provision. Meanwhile, the latter focuses on the sources of risks that may cause a failure to perform these core functions, distinguishing between economic, environmental, political, security, and societal ones, which also serve as dimensions of state fragility. At the same time, these approaches lack a coherent view on causes of state fragility defining fragility as adverse development outcomes resulting from deficiencies in formal and informal national institutions.

The review of the relevant literature identifies two groups of factors that constitute the macrohistorical dimension of state fragility. I denote the former group as structural factors. The rigidity of pre-independence colonial state borders and heterogeneity of the population and its preferences constrains collective action and prevents states from functioning with uniform efficiency within their borders. Besides, upon independence, these states faced minor external threats and did not actively participate in the

\footnotetext{
6 The group of severely fragile contexts defined by the OECD consists of the countries scoring the lowest based on six-level scale clustering and mixed-method analysis (OECD. 2018. States of Fragility 2018. Paris: OECD Publishing. P. 212. DOI: $10.1787 / 9789264302075-e n)$. Chronically fragile contexts are those considered as fragile by the organization since the inception of its States of Fragility report in 2008 (OECD. 2018. States of Fragility 2018. Paris: OECD Publishing. P. 26. DOI: 10.1787/9789264302075-en).

7 See: OECD. 2007. Principles for Good International Engagement in Fragile States and Situations. URL: https://www.oecd. org/dac/conflict-fragility-resilience/docs/38368714.pdf (accessed 10.08.2021); OECD. 2008. Accra Agenda for Action. URL: https://www.oecd.org/dac/effectiveness/34428351.pdf (accessed 10.08.2021).

8 OECD. 2016. States of Fragility 2016: Understanding Violence. Paris: OECD Publishing. DOI: 10.1787/9789264267213-en
} 
international military competition and, consequently, faced little pressure to develop effective military and tax systems. Moreover, their small economic size often means that they cannot achieve scale economies in the production of public goods and lack resources to invest in institutional capacity. The latter is comprised of agency factors. Inefficient political institutions may produce kleptocratic political regimes that do not attend to the population's interests and may even restrict access to public goods to some groups. All these factors are likely to produce gaps in performing core functions of the state and contribute to increased state fragility. I provide a more detailed explanation in the article, acknowledging that not all fragile states that this research focuses on share the highlighted characteristics.

The article is divided into three sections. Firstly, it reviews the evolution of the state fragility concept, focusing on definitions that capture in the best way the characteristics that these states exhibit and on standards of "resilience." Secondly, it reviews the literature on the causes of state fragility. Thirdly, it draws on the findings from the previous sections and related literature to provide some commentary on the processes of fragile states formation and the macrohistorical dimension of chronic and severe state fragility. In the discussion section, it critically reviews the findings and provide some remarks on the practical and analytical value of the concept itself.

\section{Modern approaches to defining state fragility}

There have been debates on stateness (what constitutes a capable and effective state, to be precise) since the breakdown of the colonial system when the number of states in the international system significantly and somewhat rapidly increased (Jackson, Rosberg 1982; Nettl 1968). In the early 1990s, it became evident that some postcolonial states showed no signs of becoming more effective, while others were in the process of disintegration. It was in these circumstances that researchers produced first attempts to categorize such states. G. Helman and S. Ratner (Helman, Ratner 1993) in their work introduced the concept of a failed state or state failure, but it remained rather broadly defined and understood as situations when "governmental institutions are overwhelmed by circumstances" (Helman, Ratner 1993: 5). Although their work helped attract scientific interest to the states they called failed, their approach was vague. They did not differentiate between degrees of state failure, neither did their analysis shed light on particular characteristics of such states (apart from them being in the process of disintegration and producing global threats).

The late 1990s saw growing attention to failed or fragile states that started to be recognized as sources of potential threats to the national security of Western states. The idea of fragility as a national security threat gained more traction after the $9 / 11$ terrorist attacks. Western governments identified fragile and failed states as implicated in the production and circulation of global threats (Fearon, Laitin 2004). Currently, this idea has not changed much. Fragile states and the problems they are plagued by (poverty, instability, ungoverned spaces) are viewed as posing a substantial threat to 
the international community (Patrick 2007) ${ }^{9}$. This understanding laid the foundation for the international military interventions in some of the states which were considered to be fragile or failed (Somalia, Afghanistan, or $\operatorname{Iraq}^{10}$ ).

The donor's interest in fragile states stemmed from a shift to aid selectivity when official development assistance (ODA) started to be primarily dedicated to countries with effective institutions and showed progress in implementing reforms proposed by the donor community and international institutions (Grimm et al. 2014). Soon it emerged that there were "bad performers" that failed to meet the standards of aid efficiency and risked being marginalized. The criticism of aid selectivity led the financial institutions to reconsider their policies and formulate specific approaches to countries they referred to as low-income countries under stress, vulnerable states, or states in crisis (Grimm et al. 2014). The "aid community" has gradually embraced fragility as a less derogative, categorical, and offensive term (Faust et al. 2015; Grävingholt et al. 2015). Since the mid-2000s, this term and its derivatives (like states of fragility or fragile contexts) have mostly replaced others in the development discourse (however, others like failed or weak state remains in use), and attempts were made at conceptualizing a definition for this group of countries.

I now proceed to review the evolution of the definitions of fragile states. Generally, they draw attention to the functions of the state either as a producer of public goods (Rotberg 2003, 2004; Zartman 1995) or as an entity that controls territory or holds a monopoly over violence (Jackson 1990; Krasner 2004). All these functions are derived from the perception of the ideal state, for instance, the Weberian state (Weber 1958). The definitions at first focused on the characteristics that fragile states lacked and tended to be descriptive. The second generation of definitions began to recognize fragility as a multi-dimensional and continuous phenomenon, focused on state institutions, and attempted to define them through authority, legitimacy, and capacity, which were understood as core functions of the state (Carment et al. 2010). Some modern definitions take a different approach and define state fragility as the inadequate coping capacity of the state to deal with and mitigate the risks they face ${ }^{11}$, which can fail to perform core functions of the state. I limit myself to reviewing the evolution of definitions, acknowledging their ambiguity, refraining from arguing which one is better for practical or analytical purposes, and not entering the debate on defining state fragility.

At first, there was a tendency to define fragile states descriptively, focusing on the characteristics these states lacked. The core characteristics of fragile or failed states were denoted as a failure of institutions, functions, and processes of a country to accord with the strong image of a sovereign state (Migdal 2001), inability to suppress

\footnotetext{
9 Burns W.J., Flournoy M., Lindborg N. 2016. Fragile States and the Next President. Foreign Affairs, 11 September, 2016. URL: https://www.foreignaffairs.com/articles/united-states/2016-09-11/fragile-states-and-next-president (accessed 10.08.2021). ${ }^{10}$ Iraq was included in the group of fragile states after its categorization as rogue states, which, supposedly, are also implicated in the production of global threats (Call 2017). However, it can be observed that this has complicated defining fragile states as a group.

11 OECD. 2016. States of fragility 2016: Understanding violence. Paris: OECD Publishing. DOI: 10.1787/9789264267213-en
} 
intrastate violence, control state territory, and economic inequality (Brooks 2005), being "a low-income country under stress." 12 "the loss of physical control of its territory or a monopoly on the legitimate use of force; the erosion of legitimate authority to make collective decisions; an inability to provide reasonable public services; the inability to interact with other states as a full member of the international community."13. However, the attempts to do so often fail to capture the complete picture as the states deemed fragile is a diverse group that at first sight may have little in common concerning internal conditions or external threats.

Since 2005 more comprehensive definitions emerged, mainly being the result of the work by donor institutions. US Agency for International Development (USAID) was among the first to propose a definition of a fragile state distinguished between states vulnerable to become fragile and states in crisis. While the former category comprised states "unable or unwilling to adequately assure the provision of security and basic services to significant portions of their populations and where the legitimacy of the government is in question" (USAID 2005: 1), states in crisis were defined as "those states where the central government does not exert effective control over its territory or is unable or unwilling to assure the provision of vital services to significant parts of its territory, where the legitimacy of the government is weak or nonexistent, and where violent conflict is a reality or a great risk" (USAID 2005: 1). The UK Department for International Development (DFID) defined fragile states as "those where the government cannot or will not deliver core functions to the majority of its people, including the poor"14. A similar definition was proposed by the OECD $(2007)^{15}$. According to the OECD, states become fragile when "state structures lack the political will and/or capacity to provide the basic functions needed for poverty reduction, development and to safeguard the security and human rights of their populations." ${ }^{16}$. The contemporary research on state fragility produced similar definitions highlighting their difficulties with the provision of essential public goods (Stewart, Brown 2009) and "the degree to which [a state] has deficits in one or all of its dimensions" (Patrick 2011: 19).

All definitions proposed in the late 2000s tended to view states whose institutions were incapable or unwilling to perform their core functions as fragile. What are these core functions? There has been some debate on what constitutes them and which are more critical, although a usual list includes monopoly over violence, control over territory, tax provision, and the provision of welfare services ${ }^{17}$ (Engberg-Pedersen et al.

\footnotetext{
12 World Bank. 2002. World Bank Group Work in Low-income Countries under Stress. A Task Force Report. Washington, DC: World Bank/Task Force on the Work of the World Bank Group in Low-income Countries Under Stress

${ }^{13}$ Fund for Peace. What does state fragility mean? URL: https://fragilestatesindex.org/frequently-asked-questions/whatdoes-state-fragility-mean/ (accessed 10.08.2021).

${ }^{14}$ DFID. 2005. Why We Need to Work More Effectively in Fragile States. London: ukaid/Department for International Development. P. 7.

${ }^{15}$ However, the organization later significantly refined it.

${ }^{16}$ OECD. 2007. Principles for Good International Engagement in Fragile States \& Situations. Paris: OECD Publishing. P. 2. 17DFID. 2005. Why We Need to Work More Effectively in Fragile States. London: ukaid/Department for International Development.
} 
2008; Political Atlas of the Modern World... 2010). A. Whaites (2008), for instance, provides a helpful distinction between "survival" and "expected" functions of the state. "Survival" functions denote the minimalistic conditions for the existence of a state which include the ability to maintain security, raise revenue, and govern through the rule of law. "Expected" functions reflect the social contract notion in the functions of the state and include the ability to meet citizens' expectations for service delivery and infrastructure development.

The OECD fragility framework typifies a departure from the public goods provision approach to defining state fragility ${ }^{18}$. The OECD defines fragility as "the combination of exposure to risk and insufficient coping capacity of the state, system and/or communities to manage, absorb or mitigate those risks. Fragility can lead to negative outcomes including violence, the breakdown of institutions, displacement, humanitarian crises or other emergencies." ${ }^{19}$. This definition presents an advantage because it emphasizes the lack of state and local informal institutions' capacity to deal with different risks that may arise. Besides, it acknowledges conflict and state collapse as potential consequences of fragility rather than its characteristics typified by the early attempts to define it.

Recent contributions to conceptualizing state fragility have recognized it as a multi-dimensional and continuous phenomenon, proposing to apply "whole of the government approach" to state fragility (Marshall, Cole 2017; Nay 2014) and recognizing that there is no clear distinction between states considered "fragile" and those deemed "not fragile" (Baliamoune-Lutz, McGillivray 2011; Lambach et al. 2015). As a departure from the concept of state failure, it is now recognized that different states are fragile to different extents (and that all states may be fragile to some extent) and that degree that matters. Thus, states are scattered over a fragility-resilience continuum, with countries being less stable and their governments performing worse being placed on the left furthermost end of this axis. As a result, issues of measuring fragility arise, but they are not discussed in this article $\mathrm{e}^{20}$.

As for the multi-dimensional nature of state fragility, there are at least two approaches to its disaggregation. The first one is inspired by the Weberian definition of the state and views fragility as the extent to which actual practices and capacity of the state differ from its idealized image (Carment et al. 2008; Carment et al. 2010). This perspective can be denoted as functionalist or the ALC approach ${ }^{21}$ (Carment et al. 2015). Authority refers to the state's ability to enforce binding regulation, exercise coercive force on the territory it controls, provide core public goods, and create enabling environment for the population. Legitimacy captures the extent to which a govern-

\footnotetext{
${ }^{18}$ OECD. 2016. States of fragility 2016: Understanding violence. Paris: OECD Publishing. DOI: 10.1787/9789264267213-en

19 Ibid. P. 73.

${ }^{20}$ For a more detailed discussion of measurement issues, see (Faust et al. 2015; Ferreira 2017; Mata, Ziaja 2009; Milante, Woolcock 2017; Patrick 2011).

${ }^{21}$ Which stands for authority (A), legitimacy (L), and capacity (C).
} 
ment commands public support for its actions, whereas capacity refers to the ability of a state to mobilize and manage resources for productive ends and progressive service delivery ${ }^{22}$.

The second approach also refers to authority, legitimacy, and capacity discourse but focuses on the sources of risks and challenges fragile states face. The recent OECD publications exemplify this approach ${ }^{23}$. Unlike the ALC approach, the OECD disaggregates fragility based on conceptual risk typology and identifies five dimensions: economic, environmental, political, security, and societal. Each dimension represents sources of potential risks. The OECD typology follows the earlier work by S.Rice and S.Patrick (Rice, Patrick 2008), who proposed economic, political, security, and social welfare functions to be viewed as the main pillars of statehood. However, the OECD approach is different as it focuses on the sources of risks that can cause a failure to perform core state functions, but not these functions per se.

A more detailed description of the approaches and their differences in defining and disaggregating state fragility is provided in Table 1.

\section{Table 1. Comparison of ALC and OECD approaches to defining and disaggregating state fragility}

\begin{tabular}{|l|l|l|}
\hline \multicolumn{1}{|c|}{ Criterion } & \multicolumn{1}{|c|}{ ALC approach } & \multicolumn{1}{c|}{ OECD approach } \\
\hline $\begin{array}{l}\text { Critical aspects of } \\
\text { defining state fragility }\end{array}$ & $\begin{array}{l}\text { Based on Weberian definition of the } \\
\text { state focuses on how effectively the state } \\
\text { performs its core functions. }\end{array}$ & $\begin{array}{l}\text { The conceptual risk typology; focuses on the state's } \\
\text { vulnerability to risks and crises resulting from its } \\
\text { institutional structure. }\end{array}$ \\
\hline $\begin{array}{l}\text { Disaggregation } \\
\text { criteria }\end{array}$ & $\begin{array}{l}\text { Core functions of the state under Webe- } \\
\text { rian typology }\end{array}$ & $\begin{array}{l}\text { Conceptual risk typology identifying sources of } \\
\text { potential risks and crises }\end{array}$ \\
\hline $\begin{array}{l}\text { Dimensions of state } \\
\text { fragility }\end{array}$ & $\begin{array}{l}\text { Organized into three dimensions - } \\
\text { authority, legitimacy, capacity - that } \\
\text { correspond to core functions of the state } \\
\text { under Weberian typology }\end{array}$ & $\begin{array}{l}\text { Organized into five dimensions - economic, envi- } \\
\text { ronmental, political, security, and societal - that } \\
\text { reflect sources of potential risks that can cause a } \\
\text { failure to perform core state functions }\end{array}$ \\
\hline $\begin{array}{l}\text { Causes of state } \\
\text { fragility }\end{array}$ & $\begin{array}{l}\text { Failure to perform essential state } \\
\text { functions effectively creates structural } \\
\text { gaps that leave a state vulnerable and } \\
\text { unstable. }\end{array}$ & $\begin{array}{l}\text { Lack of coping capacities to deliver a response to } \\
\text { risks and crises that results from deficiencies in } \\
\text { formal and informal national institutions }\end{array}$ \\
\hline $\begin{array}{l}\text { Consequences of state } \\
\text { fragility }\end{array}$ & $\begin{array}{l}\text { Failure to fulfill critical functions leads to } \\
\text { increased fragility, a higher probability of } \\
\text { conflict onset, and other emergencies. }\end{array}$ & $\begin{array}{l}\text { Failure to respond to risks and crises effectively } \\
\text { creates additional pressures and grievances, which } \\
\text { lead to increased instability and emergencies, } \\
\text { including violent conflict. }\end{array}$ \\
\hline
\end{tabular}

Sources: (Carment et al. 2008; Carment et al. 2010; Carment et al. 2015) ${ }^{24}$.

The information presented in Table 1 shows that although the two approaches agree on the consequences of fragility and view some of the critical attributes of state fragility similarly, they differ in their definitions and the ways of phenomenon dis-

\footnotetext{
${ }^{22}$ There were attempts to add a function of public finance management (Cliffe, Manning 2008) rather than include it in the state capacity dimension; however, it has not gained much popularity among academia and policymakers.

${ }^{23}$ OECD. 2020. States of Fragility 2020. Paris: OECD Publishing. DOI: 10.1787/ba7c22e7-en; OECD. 2016. States of fragility 2016: Understanding violence. Paris: OECD Publishing. DOI: 10.1787/9789264267213-en

${ }^{24}$ OECD. 2016. States of fragility 2016: Understanding violence. Paris: OECD Publishing. DOI: 10.1787/9789264267213-en
} 
aggregation. These dissimilarities come from different conceptual underpinnings on which these approaches are based. Whereas the ALC approach focuses on state performance and disaggregates state fragility following the state's key functions, the OECD approach is based on conceptual risk typology and pays specific attention to the sources of potential risks. At the same time, both approaches have not developed a thorough explanation of the causes of fragility and view them as negative outcomes that result from bad governance.

To sum up, there is a consensus that state fragility has multi-dimensional and continuous nature, although the organization of these dimensions may differ (Grävingholt et al. 2015). I argue that these approaches are complementary as risks or their combinations that fragile states face may be different and context-specific. Regardless of that, the inability to deliver an efficient response to risks and crises may stem from specific gaps inherent to fragile states.

Despite significant development in scientific thinking about state fragility, the current mainstream approach to state fragility is based on an idea of a norm and deviation from it (Bøås 2017; Patrick 2011) and, to some extent, on a "teleological belief in the convergence of all nation-states to the norm" (Hagman, Hoehne 2008: 42). Moreover, there is a tendency to define fragile states by what they are not or lack, i.e., state efficiency, whatever model is applied, be it Weberian, Tillyian, or "OECD-model" state (Eriksen 2011). However, whether these standards are universal remains debatable as different states have different informal social institutions and cultural orientations.

\section{On the causes of state fragility}

This section of the article reviews the research on the causes of state fragility (or state failure). The multi-dimensional nature of fragility suggests that there can be no single determinant of fragility as it is relatively rare that states are uniformly fragile across all dimensions (Carment et al. 2010). It is often several development problems that these states face which may not be linked directly. Hence, state fragility maybe even an issue of multiple causality. Most of the research on the causes of fragility has been quantitative and instrumental and aimed at establishing causal links between different variables (internal conflict, poverty, ethnic heterogeneity, etc.) and state fragility.

In contrast, the institutional approach has focused on national institutions and organizations that might make states vulnerable. As a result, we end up with various causes that may explain a downslide to fragility or a state of 'natural disorder.' However, most research rarely accounts for the possibility of reverse causality (probably, it is not conflicting that makes these states fragile, but fragility makes them more susceptible to violence). Consequently, the causes of such instability and vulnerability to risks remain open to debate.

I identify several streams of academic literature devoted to explaining state fragility. 
The first one is comprised mainly of comparative econometric analysis aimed at establishing causal links between variables of interest and state fragility (or its extents). The variables usually include civil conflict or war, resource dependence, onsets of violence (Aliyev 2017; Collier, Hoeffler 2004; Ross 2004). The argument is that availability of resources makes rebellion feasible (Collier et al. 2009), and combined with other socio-economic factors (poverty and deprivation, social exclusion, ethnic heterogeneity or fractionalization, repression, etc.), it may give rise to civil unrest in an attempt to resolve grievances or to gain access to resources. However, prolonged conflict results in lower quality or even absent public goods provision, which means states become even poorer and more fragile.

The second stream of the literature (institutional approach) focuses on state-society interactions and the emergence of states as limited access orders (North et al. 2012). It argues that fragility can be viewed as a type of natural order that produces the most adverse development outcomes. D. Acemoglu and J. Robinson (Acemoglu, Robinson 2012) argue that such states are inherently fragile and that they sow the seeds of their destruction by relying on clientelism, rent-seeking, and corruption as a means of maintaining power and control while repressing their population. Consequently, these states have dysfunctional economic, political, and public administration systems that increasingly rely on resource exploitation and rent-seeking by the elite. Ultimately, it means that if internal or external shocks arise, these states will lack the capacity to mitigate them and will be likely to fail at providing public goods to the population and lose control over it.

The third stream of the literature adopts a functionalist approach to explaining state fragility by looking at core functions of the state (ALC approach has been discussed previously). Fragile states exhibit structural gaps that can be disentangled across three lines - authority, legitimacy, service or capacity (Brinkerhoff 2007, Stewart, Brown 2009). Authority gaps include failure to provide security for population and property, as well as inability to control state territory. Service or capacity gaps point to the failure to provide basic public goods and infrastructure and the inability to create an enabling environment for the population's well-being. Legitimacy gaps indicate inability to form a responsive and accountable government that is capable of managing public support. According to the World Bank ${ }^{25}$, the states that fail to perform these functions risk entering a vicious cycle that makes them increasingly fragile over time. However, researchers failed to distinguish which of the government's functions was more important in explaining fragility (Takeuchi et al. 2011). Anyway, failure to fulfill these functions may lead to increased fragility, higher probability of conflict onset with a possibility of a country entering a fragility trap, when it gradually becomes increasingly fragile and moves towards disintegration (Goldstone 2008).

\footnotetext{
${ }^{25}$ World Bank. 2011. World Development Report 2011: Conflict, Security, and Development. Washington DC: World Bank.
} 
Finally, the fourth stream of the literature focuses on exogenous factors of state fragility. Among them, the authors note the spread of terrorist groups (Patrick 2007; Sandler 2015) and transnational criminal networks (Berdal, Serrano 2002; Duffield 2001) which are implicated in illicit activities and which find safe haven within the territory of the fragile states. According to the World Bank ${ }^{26}$, their activities are likely to weaken governmental institutions, foster corruption and undermine popular trust in the state institutions. Fragile states are often locked in a "bad neighborhood" problem as they have borders with other fragile states (Collier 2007). Negative outcomes in one state, consequently, may produce negative dynamics in its neighbors through spillover effects (due to forced migration, extension of conflict zone, trade shocks, etc.) (Iqbal, Starr 2008). There are also causes related to terms of trade and ecological shocks. Since fragile states have dysfunctional economic systems, they are often dependent on food imports, thus any price shock substantially increases their vulnerability. R. Burke et al. (Burke et al. 2009) and E. Miguel and S. Satyanath (Miguel, Satyanath 2011) also document that diminishing rainfalls and temperature rise create additional pressures for African states and make them subject to more risks.

There are also critical approaches which I denote here as a separate literature stream acknowledging though that they have some theoretical and methodological differences. However, they can be considered as a single one for the purposes of this article since they are critical of the concept itself and do not apply it in their analysis of the "Global South" development problems, while they also help escape some of the shortcomings of the mainstream approaches, for example, their normative nature and lack of attention to informal institutions, contextual factors and historical dynamics. There are two major streams of critique: 1) dependency and world-systems theory, 2) postdevelopment theory.

Dependency and world-systems theory posits that global inequalities produced by the colonial legacy and preserved in the post-colonial world order are major prerequisites of the development problems faced by post-colonial nations. Their dependent position in global economic and political relations that stems from unfair trade practices and lack of economic diversification deprives them of an opportunity to change their fortunes and makes them susceptible to state fragility or even failure (O'Kane 1993; Tusalem 2016; Wallerstein 2011).

Post-development theory also emphasizes the role of colonial legacies in adverse development outcomes for post-colonial nations but offers a different explanation. They are interpreted as the result of the Western formal political and economic institutions imposition on the "Global South" without due attention to contextual differences and informal institutional structures. As a consequence, these countries produce only a flawed imitation of Western institutional structures which do not correspond to local informal practices. Post-development theory is also more critical of the concept itself.

${ }^{26}$ Ibid. 
It is viewed as a reflection of Western perceptions of state efficiency, which may be viewed as universalist and derogative and which serves as a pretext for interventions and development efforts that can be counterproductive with a possibility of creating even more development problems (Call 2008; Escobar 2011; Nay 2013, 2014; Saeed 2020).

There are several problems common to all of the critical approaches. Firstly, they exhibit bias and base their positions on Marxist (or Neo-Marxist) or anti-Western political traditions ${ }^{27}$. Secondly, they see colonial legacies (though they offer different interpretations of how they affected post-colonial nations) as the major factor behind the development problems of the states referred to as fragile in this article. These approaches also blame the West for imposing institutions and model of thinking which upholds its dominance and supremacy in international relations without due attention to internal and structural factors that affect the stability of fragile states.

To sum up, there is a consensus among scholars that a single root cause of fragility does not and cannot exist, as the countries in question suffer from different problems and to different extents. Fragility, thus, cannot be attributed to an isolated influence of such factors as civil war, poverty, having weak institutions, or external shocks (Brinkerhoff 2019). There is usually a combination of variables that drives states on a trajectory towards increased vulnerability and instability. A contrasting view is offered by critical theories (dependency/world-systems theory and post-development theory) that see colonial legacies as a significant prerequisite for the emergence of weak states. However, it remains unclear why fragile states lack coping capacities.

\section{Macrohistorical context of state fragility}

This section covers the macrohistorical dimension of state fragility. Having identified that fragile states are incapable of coping with risks and shocks, I review existing literature and provide commentary on predicting severe or chronic fragility risks. It allows uncovering how the interaction between historical dynamics and the processes of their genesis accounted for the poor performance of this subgroup of states.

There is a tradition of thinking about fragile states as the antipode of effective and capable states within two competing perspectives. The first one views the state as service providers (output-oriented approach), with public goods as their primary purpose, whereas the second one is inspired by the Weberian definition of the state (Eriksen 2011). S. Eriksen (Eriksen 2011) suggests that the output-oriented approach to state performance is hardly suitable as an analytical concept when dealing with fragile states as it is closely tied to what he calls the "OECD model" and exhibits democracy bias when measuring the legitimacy of the state.

${ }^{27}$ The mainstream approaches covered in this article may not be free from similar shortcomings. 
Weberian tradition (Weber 1958) focuses on the state's institutional capacity, i.e., its ability to uphold the claim to the legitimate use of force to enforce its order. This tradition tends to disaggregate core state functions in three dimensions -authority, legitimacy, and capacity ${ }^{28}$, which loosely correspond to a "trinity" of legitimized monopolies - monopoly of rule-making, monopoly of violence, and monopoly of tax collection. Any private participation in performing core functions of the state should be authorized by it.

To shed light on the emergence of fragile states, I proceed with the analysis of their genesis. Chronically or severely fragile states often fail, at least partly, to comply with these ideal perceptions, be it "OECD-model" state or a Weberian state. As shown in the first section of the article, they are often characterized by the lack of control and capacity to enforce rules over their territory so that their institutions are likely to produce gaps across all dimensions.

Meanwhile, historical-institutionalist perspective views 'disorder' as a natural order and posits that it is the emergence of effective states that needs explanation (North et al. 2012). Nevertheless, as a Western model of statehood is recognized as a norm for national political organization, it is important to understand what historical peculiarities prevent states defined as fragile by the World Bank and the OECD from developing more effective institutional structures and producing better development outcomes. Moreover, official documents presuppose political component to development which calls for better evaluation of contextual characteristics. To produce better development outcomes for fragile states, it is important not to overlook the macrohistorical factors that make them inherently fragile.

Ch. Tilly (Tilly 1990) explains the emergence of affective states as the result of international military rivalry, which changed states from "stationary bandits" (in terms of M. Olson (Olson 1993)) to modern public goods providers ${ }^{29}$. He shows that a need to finance military activities and increasing military spending forced states to develop taxation to have secure domestic revenue sources, which allowed them to manage the debt burden. Maintaining efficient taxation systems required supporting institutions and at least maintaining security on the territories the state-controlled. Over time such states developed an interest in creating a more enabling environment for private economic activity as it helped increase their tax revenue. Therefore, they expanded the provision of public goods, accepted accountability, and developed the institutions of representation to promote wealth generation and accommodate citizens' interests. Finally, in this quest for state efficiency (which P. Collier (Collier 2009) compares to Darwinian natural selection), borders changed, and only effective states survived.

\footnotetext{
${ }^{28}$ Some authors (Lambach et al. 2017) proposed excluding legitimacy from the list for it setting too high a standard for most modern states and challenging to operationalize quantitatively.

${ }^{29}$ A similar account is presented by S.Bartolini (Bartolini 2005).
} 
As Ch. Tilly (Tilly 1990) depicts the macrohistorical dynamics of resilient states, these processes were different for the fragile states as defined by the World Bank and the OECD. P. Collier (Collier 2009) posits that their genesis was qualitatively different and, as a result, they ended up with different political economies. Firstly, this "Darwinian process" was largely absent, and fragile states mainly emerged after the break-up of empires or decolonization and often inherited the borders of former colonial entities. Secondly, unlike the "Tillyian state," they faced few external threats and did not actively participate in international conflicts. That is why they faced little pressure to develop effective and expensive military and, consequently, effective tax systems ${ }^{30}$. Thirdly, these new states tended to be divided along ethnic and sectarian lines, which made collective action and bargaining processes more difficult (Metamorfozy razdelennykh obshchestv 2020 ${ }^{31}$. In addition, some of these states were endowed with natural resources, which made efficient taxation systems not necessary. Finally, although they did not face a significant risk of international conflict, these states were far from secure and plagued by intrastate conflicts. As they did not have incentives to improve the efficiency of their institutions, they remained poor, which possibly made rebellions more viable ${ }^{32}$. However, there is a possibility of reverse causality, with conflict being the result of state fragility.

Another perspective is presented by A. Alesina and E. Spolaore (Alesina, Spolaore 1997; Alesina, Spolaore 2003), who proposed a model that addresses the number and size of nations in the international system. The size of the states and, consequently, their number is determined by the trade-off between costs and benefits of size and the costs of heterogeneity of preferences over the provision of public goods and governmental policies it entails. The efficiency of government diminishes linearly the further the point is from the center of the state. The equilibrium is achieved either by public choice, when a region decides a part to what state it becomes, or is exogenously configured by "dictatorial Leviathans". The equilibrium in the world therefore consists of an $\mathrm{N}$ number of equal-sized states with maximized average utility. The equilibrium, however, can be affected by global security threats and economic liberalization that shift it to a lower or higher number of states.

Consistent with the model's predictions (Alesina, Spolaore 1997), the number of states in a post-1945 world system substantially increased. At the same time, the authors (Alesina, Spolaore 2003) note that borders in Africa do not reflect ethnic, reli-

\footnotetext{
${ }^{30}$ Since 1945 not only have international conflicts become much rarer but also no state ended up incorporated into the other as a result of military conflict (Tir et al. 1998; Zacher 2001).

${ }^{31}$ Recent research (Arbatli et al. 2020) suggests that it may be even intra-group heterogeneity that contributes to the emergence of unstable political economies which are likely to experience conflict and state fragility. Unsurprisingly, it is the post-colonial (and mostly African) states that exhibit the highest degree of intra-group heterogeneity. In terms of the Alesina-Spolaore model (Alesina, Spolaore 1997) discussed later in the article, it means that the state's capacity to perform its core functions maybe even more unevenly distributed than predicted by the model.

32 T. Beesley and T. Persson (Beesley, Persson 2008a) confirm that at low levels of income, rebellions are both "cheap" and common.
} 
gious or cultural divisions ${ }^{33}$. Therefore, the model predicts the chaotic nature of borders in Africa and some other post-colonial regions. Consequently, the heterogeneous population of these new countries means that heterogeneity of preferences is non-linear and that the function of state effectiveness would also follow that pattern. This can explain why these new post-colonial states are inefficient in providing public goods to the population or producing better development outcomes and "economic success" as they cannot function with uniform efficiency within their state borders (Alesina et al., 2011). Consequently, they are more likely to experience chronic or severe fragility.

It can also be observed that secession or territorial change was quite rare. A. Alesina and E. Spolaore (Alesina, Spolaore 2003) attribute it to a conscious decision of African leaders. However, the UN-backed consensus on the respect for territorial integrity and the Organization of African Unity (now African Union) resolution supporting respect for inherited borders also came into being (Zacher 2001). Thus, the evolutionary process of territorial change that could create more unified and efficient states was prevented ${ }^{34}$.

By making these historical comparisons, I do not mean to say that fragile states should necessarily follow the path of state formation experienced by the "resilient" states - higher institutional effectiveness may be achieved through different means in the modern world. Instead, they are drawn from the related literature to show that the paths of state formation could create conditions that may exclude any prospect for sustainable socio-economic development. I provide explanation further in this section. Moreover, even though these dynamics may match more or less every post-1945 former colonial state, not all of them are categorized as fragile by the OECD and the World Bank. High probability of falling into fragility does not exclusively depend on the path of state formation. Consequently, there may be some specific characteristics that account for insufficient coping capacities of certain states.

Authors (Beesley, Persson 2008b; Collier 2009) also attribute fragility to small economic size of these new nations. Upon their independence, many states were extremely poor and their poverty was combined with low population size ${ }^{35}$. It prevented them from exercising scale economies in the provision of public goods, particularly security, as that in a big state, maintaining security is less costly on a per capita scale. As a result of that, relatively high military and security expenses of these states prevent them from investing in the institutional capacity. Therefore, these often small and impoverished states with chaotic borders and heterogeneous population do not command enough resources to be resilient in the face of different threats that arise and are likely to fall into the category of fragile states.

\footnotetext{
${ }^{33}$ This is also substantiated by other researchers (Herbst 2000; Michalopoulos, Papaioannou 2020). A. Alesina et al. (Alesina et al. 2011) even call states with such a configuration of their borders "artificial."

${ }^{34}$ That could serve as an explanation for why some post-colonial states are caught in the inefficient public goods provision trap.

${ }^{35}$ For GDP per capita and population data, see: World Bank. World Bank Open Data. URL: https://data.worldbank.org/ (accessed 10.08.2021).
} 
The processes of state-formation discussed above may produce authority, legitimacy and capacity gaps. That is why the core functions of the state can not be performed in due form.

Authority gaps manifest themselves in an inability to maintain a monopoly of violence or tax collection due to the costly nature of providing security as a public good. Without that, tax collection is also likely to be limited and restricted to tariff collection. Governments, consequently, would be forced to primarily rely on external sources of revenue.

Legitimacy gaps result from heterogeneity of preferences of population, which are likely to change nonlinearly due to the somewhat chaotic nature of national borders. Thus, a state would have a hard time commanding the support of the population. T. Beesley and T. Persson (Beesley, Persson 2008b) suggest that another issue concerning legitimacy may arise. Governments may get detached from the interests of the population and become irresponsive if they rely on tariffs as a source of revenue ${ }^{36}$.

Capacity gaps may occur due to a lack of incentives to strengthen national institutions as states of small economic size are more likely to fall prey to rebellions and civil wars. As a result, maintaining military expenditure ends up crowding out non-military expenses, while heterogeneity of the population and its preferences means that a state can not be uniformly effective in different parts of its territory. A combination of these problems may create a state we would call fragile or even extremely fragile depending on the extent of the problems it encounters.

S. Michalopoulos and E. Papaioannou (Michalopulos, Papaioannou 2020) show how historical legacies and structural factors that were described in this section create increasingly unstable and fragile states in Africa. Their review notes that colonialism, though short, established borders that did not reflect the ethnic composition of the territories and institutional structures that were primarily aimed at exploiting the continent's riches (Michalopoulos, Papaioannou 2014). The provision of public goods in these countries was limited to capitals and significant urban hubs (Michalopoulos, Papaioannou 2014). Upon independence, the population of African states was poor and heterogeneous, while the institutions in place were unable to enact policies that would allow infrastructure or human capital development needed for economic growth. The relative poverty of these new states and the extractive nature of institutions meant that governments lacked interest in developing more effective tax systems since they depended on foreign trade as their primary source of income. This prevented the effective functioning of the institutions of representation and investment in infrastructure. In contrast, heterogeneity of population meant that it was difficult for the governments to rely on the support of the whole population, which created the potential for violent conflict that further destabilized some states.

\footnotetext{
${ }^{36} \mathrm{~J}$. Weigel (Weigel 2020) suggests that lack of incentive and capacity to develop direct tax collection in fragile settings may also explain low levels of political participation, which could improve the quality of institutions, and to some extent, may be attributed to a conscious decision by the political elites of such states.
} 
The author provides some commentary on the inconsistencies in the generalizations taken from the literature. This review focuses on factors that may help explain state fragility, and by that, the author does not mean that all states categorized as fragile by the international institutions share all of the characteristics highlighted in the previous paragraphs. There are some counterexamples - DRC is not of small economic size though its population is impoverished, and it matches most of the other characteristics this review finds (Weigel 2020). It is better to think of the characteristics highlighted in the article as potential variables that may be expected to be positively correlated with the degree of observed state fragility. The more these characteristics a state exhibits, the higher degree of state fragility would hypothetically be observed.

As the article has covered some structural gaps that may explain macrohistorical dynamics of the emergence of fragile states, there is also a group of factors referred to as agency problems. Firstly, as fragile states tend to have weak political institutions and the population may have little say or control over decision-making, the political leaders of such states may pursue their benefit, which may lead to the formation of kleptocratic and corrupt political regimes (Acemoglu, Robinson 2012; De Waal 2014; Herbst 2000). Consequently, such regimes are unlikely to produce economic gains for the population and are likely to generate additional grievances that contribute to increased fragility. Secondly, such weak institutional structures may substitute the provision of public goods with the provision of club goods, deliberately denying access to them for some groups of the population ${ }^{37}$ (Alesina et al. 2011).

A. De Waal (De Waal 2014) shows how the factors described in the previous paragraph can lead to state collapse. He observes that South Sudanese governance has long been neo-patrimonial and kleptocratic and has retained these features upon independence. Moreover, the population of the country is heterogeneous, and leading political groups claim to represent the interests of different groups of the population. Organized violence is often used as a means of bargaining, which leads to internal instability and violence ending in the redistribution of resources, but not in better governance. As a result, access to public goods relied on unstable client-patron relations that were subject to renegotiation, use of force was widespread and cyclical, while military expenses reached as high as $10 \%$ GDP. As the quality of institutions remained poor, South Sudan entered what may be called a "fragility trap."

The macrohistorical dimension of state fragility analysis indicates that although risks and threats are context-specific, fragile states as defined by the World Bank and OECD share some patterns of state-formation processes that may make them vulnerable and more likely to fall into the category of fragile. Firstly, they are primarily postcolonial states that inherited colonial borders. Second, with their population being heterogeneous and often divided along sectarian, ethnic, and cultural lines, they face collective action problems because of high transaction costs, which may prevent them

\footnotetext{
${ }^{37}$ OECD. 2009. Service Delivery in Fragile Situations: Key Concepts, Findings, and Lessons. OECD Journal of Development. 9(3). P. 7-60. DOI: 10.1787/journal_dev-v9-art26-en.
} 
from bargaining and establishing better institutions. Thirdly, a common characteristic of fragile states is the small economic size (low population size coupled with low per capita income) which means that they cannot reap economies of scale in the provision of security and other public goods. As a result, they also lack resources to invest in state capacity due to negligible tax bases.

Along with these structural gaps, there are also agency problems that may explain state fragility. Imperfect political institutions may produce kleptocratic political regimes detached from the population's interests and irresponsive to them. At the same time, there is also a possibility for some groups to be denied access to the public good or to be subject to limited access. These factors may further undermine state capacity and produce increasingly fragile states. Of course, there are exceptions to these generalizations, but most of the fragile states as defined by the OECD or the World Bank, i.e., extremely or chronically fragile, may be expected to fit the pattern of stateformation described in the article.

\section{Results}

The literature review finds significant advancement in defining a group of states that are vulnerable to risks and crises and cannot produce an efficient response to them despite some inconsistencies and ambiguity in the application of state fragility concept. Since the mid-2000s, these states have been mostly referred to as fragile states; however, its derivates and other terms (like weak states, failed states) remain in use and are often applied in a synonymous way. Despite fragility being a multi-dimensional and continuous phenomenon, which means that fragile states may suffer from different problems and to different extent, the defining characteristic of a fragile state is its vulnerability to risks and crises and inability to cope with them.

The article also finds there is a consensus among scholars that a single root cause of fragility does not and cannot exist. Therefore, state fragility cannot be attributed to an isolated influence of such variables as civil war, poverty, weak institutions, or external shocks, with a combination of factors that drive state fragility. However, the literature review presented in the second section of the article explains the change in the degree of fragility rather than its emergence.

Besides, the diversity of potential causes of state fragility and structural gaps that it manifests itself in makes the concept ambiguous and points to the need to search for a more solid ground to identify fragile states. This article argues that this can be effected by analyzing the macrohistorical dimension of state fragility - the processes and dynamics of state formation and development. This review indicates that chronically or extremely fragile states share some patterns of state-formation processes that may make them vulnerable and likely to fall into the category and distinguishes them from more solid and resilient states.

The literature review presented in the article discovers several macrohistorical factors that may explain why states are likely to be weak and fragile and categorizes them 
into two groups - structural gaps and agency problems. Firstly, fragile states are mostly post-colonial states that inherited colonial borders. Secondly, with their population being heterogeneous and often divided along sectarian, ethnic, and cultural lines, they face collective action problems that may prevent better institutions. Thirdly, a common characteristic of fragile states is their small economic size which means that they lack resources to provide public goods to their population. As a result, they also lack resources to invest in state capacity due to negligible tax bases.

Along with these structural gaps, there are also agency problems that may explain state fragility. Imperfect political institutions may produce kleptocratic political regimes that are detached from the population's interests and irresponsive to them, while there is also a possibility for some groups to be denied or be subject to limited access to public goods. A combination of these factors is likely to produce states that are weak and fragile across multiple dimensions.

\section{Discussion}

As the concept of state fragility is subject to criticism from scholars (the same holds for the concepts of failed or weak states), there is a critical issue to be raised here. As shown in the article, these states' state formation processes and their limited capacity in terms of public goods provision are often seen as a "deviation from the norm" (Bilgin, Morton 2004; Eriksen 2011), with the norm being a resilient Western state. However, the state fragility concept may be seen as progress in scientific thinking about states that do not produce positive outcomes for the population. It remains a matter of debate whether it is helpful to apply this general framework of statehood to non-Western states that fail to emulate it for the reasons described in the previous sections of the article.

The criticism thus focuses on several aspects of the concept. Firstly, it implies that if institutions of these states are inherently different, they can produce only a flawed imitation of the model (Hansen, Stepputat 2001). Secondly, it argues that the concept is of limited analytical utility because it is applied in wildly divergent and problematic ways (Call 2012; Nay 2014). Thirdly, it serves as a ground for sometimes counterproductive international interventions.

This article argues that a concept of state fragility holds its analytical and practical value. Firstly, formal institutions of all (or at least most) states are still based on the European model of statehood, and leaders of post-colonial states raise no objections to that (Alesina, Spolaore 2003). Second, this modern state model is globally recognized as a political unit (Eriksen 2011). Therefore, states that fail to perform their functions and react to risks and crises can be viewed as fragile. It may be argued that given the diversity of fragile contexts and their development problems, this concept may obscure reality rather than help better understand it. However, this research finds that some macrohistorical factors provide a more solid ground for identifying state fragility - at least if a subgroup of severely and chronically fragile states is considered. 
The analytical and practical value of the concept is also demonstrated that fragile states are at the highest risk of failing to achieve Sustainable Development Goals (SDG). Economic development and social progress remain uneven, and there are prospects of them producing regional or global threats through spillover effects (because of conflict, human flight, transnational crime, etc.) ${ }^{38}$ (Iqbal, Starr 2008). As these countries do not command enough resources or institutional capacity to cope on their own, international institutions and donor agencies correctly pay special attention to them. Whereas better economic outcomes for the less developed countries and increased political stability remain at least a desirable result of global development efforts, identifying states affected by severe and chronic fragility, along with a better understanding of what makes them fragile, may be helpful in decision making and priorities selection for the official development assistance ${ }^{39}$. Improved and more acknowledged development policies are critical amidst the COVID-19 pandemic as fragile states suffer from not only internal problems (insufficient infrastructure and funds to cope with the spread of the disease) but are also subject to potential external shocks such as food security and price shocks, restrictions on the movement of people, the decline in international aid due to internal pressures donors face ${ }^{40}$.

Though the findings of this review remain speculative, they open avenues for further research. The results could be substantiated by quantitative analysis linking the expected state fragility based on the peculiarities of the state-formation process this article uncovered with the observed data.

States may be vulnerable or at risk of failure even before they are acknowledged as failing or fragile. Pathways to fragility are relatively easy to establish, and there is no lack of empirical research linking fragility to conflict, poverty, deteriorating ecological or economic conditions. However, this view on fragility lacks a macrohistorical perspective: what makes a state likely to become chronically fragile?

The author answered this question by looking at macrohistorical dynamics of the states that fall into the category as defined by the World Bank and the OECD. The review of the literature presented in the article finds that they are qualitatively different. Unlike the models of statehood reflected in Weberian or Tillyian tradition, most fragile states are post-colonial and have a heterogeneous population, which may increase the heterogeneity of population preferences for public goods and governmental policies. In combination with their small economic size, it means that they are likely to be inefficient in both providing public goods and responding to crises. Therefore, they

\footnotetext{
${ }^{38}$ OECD. 2018. States of Fragility 2018. Paris: OECD Publishing. DOI: 10.1787/9789264302075-en

$39 \mathrm{lbid}$.

${ }^{40}$ OECD. 2020. Covid-19, Crises and Fragility. URL: https://www.oecd.org/coronavirus/policy-responses/covid-19-crisesand-fragility-2f17a262/ (accessed 10.08.2021).
} 
are likely to experience higher degrees of state fragility and suffer from a multitude of development problems.

The article also provides justification for the application of the concept. According to its findings, fragile states do have common characteristics with regard to the dynamics of their formation and development. Therefore, identification of the group of countries which are the most vulnerable to risks and crises may help build a more stable and equal global environment through targeted development strategies based on a more solid scientific ground.

\title{
About the author:
}

Denis P. Elagin - lecturer, Moscow State Institute of International Relations (University) of the Russian Ministry of Foreign Affairs, 76 Vernadskogo avenue, Moscow, Russia, 119454; assistant, Peoples Friendship University of Russia, 6 Miklukho-Maklaya street, Moscow, Russia, 117198.

E-mail:d.elagin@my.mgimo.ru, elagin-dp@rudn.ru

\section{Conflict of interests:}

The author declares the absence of conflict of interests.

\section{Acknowledgements:}

The research was funded by RFBR, project no. 20-011-00922.

\section{Концептуальные подходы}

\section{к анализу «неустойчивости государств»}

\author{
Д.П. Елагин \\ DOI 10.24833/2071-8160-2021-4-79-107-135
}

Московский государственный институт международных отношений (университет) МИД России, Российский университет дружбы народов (РУДН)

Представленный в статье анализ научного дискурса по проблематике «государственной неустойчивости» направлен на критическое переосмысление значимости факторов, с которыми обычно связывают уязвимость некоторых государств к рискам и кризисам и их неспособность найти ресурсы для самостоятельного противостояния им. В поисках ответа автор рассматривает концепт «неустойчивых государств» и предлагает обзор литературы, посвящённой различным аспектам «государственной не- 
устойчивости». Проведённое исследование позволяет говорить о том, что учёные и эксперты добились значительных успехов в концептуализации этого феномена и осветили его многомерный характер. В частности, в результате детализации концепта возникли такие новые подходы к причинам «государственной неустойчивости», как функционалистский или ALC и подход ОЭСР. Однако эти подходы (и основанные на них практики помощи развитию) исходят из оценки функционирования «неустойчивых государств» как отклонения от нормативной модели национального государства европейского происхождения. Таким образом, в современных условиях необходимо учитывать и траектории формирования государств этой группы, т.е. анализировать макроисторическое измерение «государственной неустойчивости». Представленный в статье обзор исследовательской литературы позволяет обратить внимание на такие структурные факторы «неустойчивости», как сохранение границ колониального периода и гетерогенность населения и его предпочтений (что ограничивает способность индивидов к коллективному действию), а также малый размер экономики, в результате чего «неустойчивые государства» часто не обладают достаточной налоговой базой для эффективного предоставления общественных благ. Не менее важными являются и агентивные факторы: слабость политических институтов способствует формированию клептократий, которые отстраняются от интересов населения и могут ограничивать доступ к общественным благам для определенных групп. По мнению автора, учёт выраженности влияния рассмотренных в статье факторов позволит лучше учитывать качество и степень «государственной неустойчивости», которая демонстрирует высокую зависимость от контекстуальных характеристик, и разрабатывать более эффективные меры в сфере развития.

Ключевые слова: «неустойчивые государства», неустойчивые государственные состояния, причины «государственной неустойчивости», политическая экономия «государственной неустойчивости», «несостоявшиеся государства», государственная несостоятельность.

\section{Об авторе:}

Елагин Денис Павлович - преподаватель, Московский государственный институт международных отношений (университет) МИД России, 119454, Россия, г. Москва, пр. Вернадского, д. 76; ассистент, Российский университет дружбы народов (РУДН), 117198, Россия, г. Москва, ул. Миклухо-Маклая, д. 6. E-mail: d.elagin@my.mgimo.ru, elagin-dp@rudn.ru

\section{Конфликт интересов:}

Автор заявляет об отсутствии конфликта интересов.

\section{Благодарности:}

Исследование было подготовлено в рамках поддержанного РФФИ проекта № 20-01100922.

\section{References:}

Acemoglu D., Robinson J.A. 2012. Why Nations Fail: The origins of Power, Prosperity and Poverty. New York: Crown Books.

Alesina A., Spolaore E. 1997. On the Number and Size of Nations. The Quarterly Journal of Economics. 112(4). P. 1027-1056. DOI: 10.1162/003355300555411

Alesina A., Spolaore E. 2003. The Size of Nations. Cambridge, Massachusetts: The MIT Press.

Alesina A., Easterly W., Matuszeski J. 2011. Artificial States. Journal of European Economic Association. 9(2). P. 246-277. DOI: 10.1111/j.1542-4774.2010.01009.x 
Aliyev H. 2017. Precipitating State Failure: Do Civil Wars and Violent Non-State Actors Create Failed States? Third World Quarterly. 38(9). P. 973-1989. DOI: 10.1080/01436597.2017.1319276

Arbatli C.E., Ashraf Q.H., Galor O., Clemp M. 2020. Diversity and Conflict. Econometrica . 88(2). P. 727-797. DOI: 10.3982/ECTA13734

Ault J.K., Spicer A. 2019. State Fragility as a Multi-Dimensional Construct for International Entrepreneurship Research and Practice. Asia Pacific Journal of Management. №37. P. 981-1011. DOI: 10.1007/s10490-018-09641-1

Baliamoune-Lutz M., McGillivray M. 2011. State Fragility: Concept and Measurement. Fragile States: Causes, Costs, and Responses. Naudé W., Santos-Paulino A.U., McGillivray M. (eds.). Oxford: Oxford University Press. P. 33-42. DOI: 10.1093/acprof:oso/9780199693153.001.0001

Bartolini S. 2005. Restructuring Europe: Centre Formation, System Building and Political Structuring between the Nation-State and the European Union. New York: Oxford University Press.

Berdal M., Serrano M. 2002. Transnational Organized Crime and International Security: the New Topography. Transnational Organized Crime and International Security: Business as Usual? Berdal M., Serrano M. (eds.) Boulder, Colorado: Lynne Rienner Publishers. P. 197-207.

Besley T.J., Persson T. 2008a. The Incidence of Civil War: Theory and Evidence. NBER Working Paper №14585. Cambridge, Massachusetts: National Bureau of Economic Research.

Besley T.J., Persson T. 2008b. Wars and State Capacity. Journal of the European Economic Association. 6(2-3). P. 522-530. DOI: 10.1162/JEEA.2008.6.2-3.522

Bilgin P., Morton A.D. 2004. From 'Rogue'to 'Failed'states? The Fallacy of Short-Termism. Politics. 24(3). P. 169-180. DOI: 10.1111/j.1467-9256.2004.00217.x

Brinkerhoff D.W. (Ed.) 2007. Governance in Post-Conflict Societies: Rebuilding Fragile States. New York: Routledge.

Brinkerhoff D.W. 2011. State Fragility and Governance: Conflict Mitigation and Subnational Perspectives. Development Policy Review. 29(2). P. 131-153. DOI: 10.1111/j.14677679.2011.00529.x

Brinkerhoff D.W. 2019. State Fragility, International Development Policy, and Global Responses. The Oxford Handbook of Global Policy and Transnational Administration. Stone D., Moloney K. (eds.). New York: Oxford University Press. DOI: 10.1093/oxfordhb/9780198758648.013.4

Brooks R.E. 2005. Failed States, or the State as Failure? The University of Chicago Law Review. 72(4). P. 1159-1196.

Bøås M. 2017. Fragile States as the New Development Agenda? Forum for Development Studies. 44(1). P. 149-154. DOI: 10.1080/08039410.2017.1264737.

Burke M.B., Miguel E., Satyanath S. Dykema J., Lobell D. 2009. Warming Increases the Risk of Civil War in Africa. Proceedings of the National Academy of Sciences. 106(49). P. 2067020674. DOI: 10.1073/pnas.0907998106

Buterbaugh K.N., Calin C., Marchant-Shapiro T. 2017. Predicting Revolt: Fragility Indexes and the Level of Violence and Instability in the Arab Spring. Terrorism and Political Violence. 29(3). P. 483-508. DOI: 10.1080/09546553.2015.1049343

Call CT 2011. Beyond the 'Failed State': Toward Conceptual Alternatives. European Journal of International Relations. 17(2). P. 303-326. DOI: 10.1177/1354066109353137

Call CT 2017. The Lingering Problem of Fragile States. The Washington Quarterly. 39(4). P. 193-209. DOI: 10.1080/0163660X.2016.1261560

Carment D., Landry J., Samy Y., Shaw S. 2015. Towards a Theory of Fragile state Transitions: Evidence from Yemen, Bangladesh and Laos. Third World Quarterly. 36(7). P. 1316-1332. DOI: 10.1080/01436597.2015.1037830 
Carment D., Prest S., Samy Y. 2010. Security, Development, and the Fragile State: Bridging the Gap between Theory and Policy. London: Routledge. DOI:10.1093/acprof:o so/9780199693153.001.0001

Carment D., Samy Y., Prest S. 2008. State Fragility and Implications for Aid Allocation: An Empirical Analysis. Conflict Management and Peace Science. 25(4). P. 349-373. DOI: $10.1080 / 07388940802397509$

Chauvet L., Collier P. 2004. Development Effectiveness in Fragile States: Spillovers and Turnarounds. Centre for the Study of African Economies, Department of Economics, Oxford University (Mimeo).

Cliffe S., Manning N. 2008. Practical Approaches to Building State Institutions. Building States to Build Peace. Call CT and Wyeth V (eds.). Boulder, Colorado: Lynne Rienner Publishers. P. 163-184.

Collier D., Mahon J.E. 1993. Conceptual "Stretching" Revisited: Adapting Categories in Comparative Analysis. American Political Science Review. 87(4). P. 845-855. DOI: $10.2307 / 2938818$

Collier P. 2007. Bottom Billion: Why the Poorest Countries Are Failing and What Can Be Done About It. New York: Oxford University Press.

Collier P. 2009. The Political Economy of State Failure. Oxford Review of Economic Policy. 25(2). P. 219-240. DOI: 10.1093/oxrep/grp013

Collier P., Hoeffler A. 2004. Greed and Grievance in Civil War. Oxford Economic Papers. 56(4). P. 563-595. DOI: $10.1093 /$ oep/gpf064

Collier P., Hoeffler A., Rohner D. 2009. Beyond Greed and Grievance: Feasibility and Civil War. Oxford Economic Papers. 61(1). P. 1-27. DOI: 10.1093/oep/gpn029

De Waal A. 2014. When Kleptocracy Becomes Insolvent: Brute Causes of the Civil War in South Sudan. African Affairs. 113(452). P. 347-369. DOI: 10.1093/afraf/adu028

Di John J. 2010. The Concept, Causes, and Consequences of Failed States: A Critical Review of the Literature and Agenda for Research with Specific Reference to Sub-Saharan Africa. European Journal of Development Research 22(1). P. 10-30. DOI: 10.1057/ejdr.2009.44

Duffield M. 2001. Governing the Borderlands: Decoding the Power of Aid. Disasters 25(4). P. 308-320. DOI: 10.1111/1467-7717.00180

Engberg-Pedersen L., Andersen L., Stepputat F., Jung D. 2008. Fragile Situations: Background Papers. DIIS Report 2008: 11. Copenhagen: Danish Institute for International Studies.

Eriksen S.S. 2011. "State Failure" in Theory and Practice: the Idea of the State and the Contradictions of State Formation. Review of International Studies. 37(1). P. 229-247. DOI: 10.1017/ S0260210510000409

Escobar A. 2011. Encountering Development: The Making and Unmaking of the Third World. Princeton: Princeton University Press.

Faust J., Grävingholt J., Ziaja S. 2015. Foreign Aid and the Fragile Consensus on State Fragility. Journal of International Relations and Development. 18(4). P. 407-427. DOI: 10.1057/ jird.2013.23

Fearon J.D., Laitin D.D. 2004. Neotrusteeship and the Problem of Weak States. International security. 28(4). P. 5-43.

Feeny S., McGillivray M. 2009. Aid Allocation to Fragile States: Absorptive Capacity Constraints. Journal of International Development. 21(5). P. 618-632. DOI: 10.1002/jid.1502

Ferreira I.A. 2017. Measuring State Fragility: a Review of the Theoretical Groundings of Existing Approaches. Third World Quarterly. 38(6). P. 1291-1309. DOI: 10.1080/01436597.2016.1257907 
Gisselquist R.M. 2014. Aid and Institution-Building in Fragile States: What do We Know? What Can Comparative Analysis Add? The ANNALS of the American Academy of Political and Social Science. 656(1). P. 6-21. DOI: 10.1177/0002716214546991

Gisselquist R.M. 2015. Good Aid in Hard Places: Learning from 'Successful' Interventions in Fragile Situations. International Peacekeeping. 22(4). P. 283-301. DOI: 10.1080/13533312.2015.1059732

Goldstone J.A. 2008. Pathways to State Failure. Conflict Management and Peace Science. 25(4). P. 285-296. DOI: 10.1080/07388940802397343

Grävingholt J., Ziaja S., Kreibaum M. 2015. Disaggregating State Fragility: a Method to Establish a Multi-dimensional Empirical Typology. Third World Quarterly. 36(7). P. 1281-1298. DOI: $10.1080 / 01436597.2015 .1038340$

Grimm S., Lemay-Hébert N., Nay O. 2014. 'Fragile States': Introducing a Political Concept. Third World Quarterly. 35(2). P. 197-209. DOI: 10.1080/01436597.2013.878127

Hansen T.B., Stepputat F. (eds.). 2001. States of Imagination: Ethnographic Explorations of the Postcolonial State. Durham, North Carolina: Duke University Press.

Hagmann T., Hoehne MV 2009. Failures of the State Failure Debate: Evidence from the Somali Territories. Journal of International Development. 21(1). P. 42-57. DOI: 10.1002/jid.1482

Helman G.B, Ratner S.R. 1993. Saving Failed States. Foreign Policy. 89(4). P. 3-20.

Herbst J. 2000. States and Power in Africa: Comparative Lessons in Authority and Control. Princeton, New Jersey: Princeton University Press.

Iqbal Z., Starr M. 2008. Bad Neighbors: Failed States and Their Consequences. Conflict Management and Peace Science. 25(4). P. 315-331. DOI: 10.1080/07388940802397400

Ismail A.A. 2016. The Political Economy of State Failure: A Social Contract Approach. Journal of Intervention and Statebuilding. 10(4). P. 513-529. DOI: 10.1080/17502977.2016.1192825

Jackson R.H. 1990. Quasi-States: Sovereignty, International Relations and the Third World. New York: Cambridge University Press.

Jackson R.H., Rosberg C.G. 1982. Why Africa's Weak States Persist: The Empirical and the Juridical in Statehood. World Politics. 35(1). P. 1-24. DOI: 10.2307/2010277

Krasner S. 2004. Sharing Sovereignty: New Institutions for Collapsed and Failing States. International Security 29(2). P. 85-120.

Lambach D., Johannis E., Bayer M. 2015. The Causes of State Collapse: Results from a QCA Analysis. COMPAS Working Paper/ 2015-80.

Marshall M.G., Cole B.R. 2017. State Failure: The Problem of Complex Societal-Systems. In: Stohl M., Lichbach M.I., Grabovsky P.N. (eds.) States and Peoples in Conflict: Transformations of Conflict Studies. New York: Routledge. P. 184-207.

Mata J.F., Ziaja S. 2009. Users' guide on measuring fragility. Bonn: German Development Institute/UNDP.

Michalopoulos S., Papaioannou E. 2014. National Institutions and Subnational Development in Africa. The Quarterly Journal of Economics. 129(1). P. 151-213. DOI: 10.1093/qje/qjt029

Michalopoulos S., Papaioannou E. 2020. Historical Legacies and African Development. Journal of Economic Literature. 58(1). P. 53. 128 p. DOI: 10.1257/jel.20181447

Milante G., Woolcock M. 2017. New Approaches to Identifying State Fragility. Journal of Globalization and Development. 8(1). P. 1-10. DOI: 10.1515/jgd-2017-0008

Migdal J.S. 1988. Strong Societies and Weak States: State-Society Relations and State Capabilities in the Third World. Princeton, New Jersey: Princeton University Press. 
Migdal J.S. 2001. State in Society: Studying How States and Societies Transform and Constitute Each Other. New York: Cambridge University Press.

Miguel E., Satyanath S. 2011. Re-Examining Economic Shocks and Civil Conflict. American Economic Journal: Applied Economics. 3(4). P. 228-232. DOI: 10.1257/app.3.4.228

Naudé W., Santos-Paulino A.U., McGillivray M. (eds.). 2011. Fragile States: Causes, Costs, and Responses. Oxford: Oxford University Press.

Nay O. 2013. Fragile and Failed States: Critical Perspectives on Conceptual Hybrids. International Political Science Review. 34(3). P. 326-341. DOI:10.1177/0192512113480054

Nay O. 2014. International Organisations and the Production of Hegemonic Knowledge: How the World Bank and the OECD Helped Invent the Fragile State Concept. Third World Quarterly. 35(2). P. 210-231. DOI: 10.1080/01436597.2014.878128

North D.C., Wallis J.J., Webb S.B., Weingast B. 2012. Limited access Orders. In the Shadow of Violence: Politics, Economics, and the Problems of Development. North DC, Wallis JJ, Webb SB, Weingast B. (eds.). New York: Cambridge University Press. P. 1-23. DOI: 10.1017/ CBO9781139013611.001

Nettl J.P. 1968. The State as a Conceptual Variable. World Politics. 20(4). P. 559-592. DOI: $10.2307 / 2009684$

Patrick S. 2007. "Failed” States and Global Security: Empirical Questions and Policy Dilemmas. International Studies Review. 9(4). P. 644-662.

Patrick S. 2011. Weak Links: Fragile States, Global Threats, and International Security. Oxford: Oxford University Press.

Melville A., Polunin Y., Ilyin M., Mironyuk M., Timofeev I., Meleshkina E., Vaslavskiy Y. (eds.). 2010. Political Atlas of the Modern World: An Experiment in Multidimensional Statistical Analysis of the Political Systems of Modern States. Chicester, United Kingdom: WileyBlackwell. DOI: 10.1002/9781444327540

Olson M. 1993. Dictatorship, Democracy, and Development. American Political Science Review. 87(3). P. 567-576. DOI: 10.2307/2938736

O'Kane R. 1993. Coups d'Etat in Africa: A Political Economy Approach. Journal of Peace Research. 30(3). P. 251-270. DOI: 10.1177/0022343393030003002

Rice S.E., Patrick S. 2008. Index of State Weakness in the Developing World. Washington, DC: Brookings Institution.

Rotberg R.I. 2002. The New Nature of Nation-State Failure. The Washington Quarterly. 25(3). P. 83-96. DOI: 10.1162/01636600260046253.

Ross M.L. 2004. What Do We Know about Natural Resources and Civil War? Journal of Peace Research. 41(3). P. 337-356. DOI: 10.1177/0022343304043773

Saeed R. 2020. The Ubiquity of State Fragility: Fault Lines in the Categorisation and Conceptualisation of Failed and Fragile States. Social \& Legal Studies. 29(6). P. 767-789. DOI: $10.1177 / 0964663920906453$

Sandler T. 2015. Terrorism and Counterterrorism: an Overview. Oxford Economic Papers. 67(1). P. 1-20. DOI: 10.1093/oep/gpu039

Stewart S., Brown G. 2009. Fragile States. CRISE Working Paper №51. Oxford: University of Oxford.

Takeuchi S., Murotani R., Tsunekawa K. 2011. Capacity Traps and Legitimacy Traps: Development Assistance and State Building in Fragile Situations. Kharas K., Makino K., Jung W. (eds.) Catalyzing Development: A New Vision for Aid. Washington DC: Brooking Institution Press. P. 127-154. 
Taylor S.A.J. 2014. Fragile and Conflict-Affected States: Exploring the Relationship between Governance, Instability and Violence. Stability. 3(1). DOI: 10.5334/sta.dy

Tilly C. 1990. Coercion. Capital, and European States, AD 990-1992. Cambridge, Massachusetts: Basil Blackwell.

Tir J., Schafer P., Diehl P.F., Goertz G. 1998. Territorial Changes, 1816-1996: Procedures and Data. Conflict Management and Peace Science. 16(1). P. 89-97. DOI: 10.1177/073889429801 600105

Jerusalem RF 2016. The Colonial Foundations of State Fragility and Failure. Polity. 48(4). P. 445-495. DOI: 10.1057/s41279-016-0006-4

USAID. 2005. Fragile States Strategy, Pd-Aca-999, January 2005. Washington, DC: US Agency for International Development.

Wallerstein I. 2011. The Modern World-System I: Capitalist Agriculture and the Origins of the European World-Economy in the Sixteenth Century. Los Angeles: University of California Press.

Weber M. 1958. Politics as a Vocation. From Max Weber: Essays in Sociology. Gerth H.H. and Wright Mills C. (eds.). New York: Oxford University Press. P. 77-128.

Weigel J.L. 2020. The Participation Dividend of Taxation: How Citizens in Congo Engage More with the state When it Tries to Tax Them. The Quarterly Journal of Economics. 135(4). P. 1849-1903. DOI: 10.1093/qje/qjaa019

Whaites A. 2008. States in Development: Understanding State-Building. A DFID Working Paper. London: Department for International Development.

Zacher M.W. 2001. The Territorial Integrity Norm: International Boundaries and the Use of Force. International Organization. 55(2). P. 215-250. DOI: 10.1162/00208180151140568

Zartman I.W. 1995. Introduction: Posing the problem of state collapse. Collapsed States: The Disintegration and Restoration of Legitimate Authority. Zartman I.W. (ed.). Boulder, Colorado: Lynne Rienner Publishers. P. 1-11.

Bartenev V.I. 2017. Ot "nesostoiavshikhsia gosudarstv" k "neustoichivym sostoianiiam": logika poniatiinoi ekvilibristiki [From «Failed States' to «States of Fragility: Logic of Conceptual Acrobatics]. Polis. Politicheskie issledovaniia. №2. P. 26-41. DOI: 10.17976/jpps/2017.02.03 (In Russian)

Ilyin M.V. 2011. Predely Gosudarstvennoi Sostoiatel"nnosti Stran Mira [Varying Ranges of Individual Countries Stateness]. Political Science. №2. P. 60-75. (In Russian)

Kudryashova I.V., Kharitonova O.G. (eds.) 2020. Metamorfozy razdelennykh obshchestv [Metamorphoses of Divided Societies]. Moscow: MGIMO-University. (In Russian)

Shevskiy D. 2017. Mekhanizmy krusheniia gosudarstv (makrosotsiologicheskii podkhod) [The Mechanisms of State Collapse (a Macro-Sociological Approach)]. Sotsiologicheskoe obozrenie. 16(2). P. 89-110. (In Russian)

\section{Список литературы на русском языке:}

Бартенев В.И. 2017. От «несостоявшихся к государств» К «неустойчивым состояниям»: логика понятийной эквилибристики. Полис. Политические исследования. № 2. C. 26-41. DOI: 10.17976/jpps/2017.02.03

Ильин М.В. 2011. Пределы государственной состоятельности стран мира. Политическая наука. №2. С. 60-75. 
Кудряшова И.В., Харитонова О.Г. (ред.). 2020. Метаморфозы разделённых обществ. Москва: МГИМО-Университет. 284 с.

Шевский Д. 2017. Механизмы крушения государств: макросоциологический подход. Социологическое обозрение. №2. С. 89-110. DOI: 10.17323/1728-192X-2017-2-89-110 